\title{
ラーメン骨組の最適設計における遺伝アルゴリズムの改善提案 PROPOSAL OF AN ENHANCED GENETIC ALGORITHM FOR THE OPTIMUM DESIGN OF STEEL STRUCTURAL PLANE FRAMES
}

\author{
清 水 斉*, 澤田樹一郎**, 松尾 彰*** \\ Hitoshi SHIMIZU, Kiichiro SAWADA and Akira MATSUO
}

\begin{abstract}
This paper presents an enhanced genetic algorithm with a randomized line search technique to improve the convergence and accuracy ratio. The presented technique is the simple one-dimensional search in which design variable axes are selected randomly as the search direction. The presented algorithms are applied to the discrete sectional optimization problems to achieve the minimum structural weight and the minimum structural cost of the 3 -story and 5-story steel structural plane frames. The numerical results obtained by the presented algorithm are compared with those obtained by the conventional genetic algorithm to check the effectiveness.
\end{abstract}

Keywords: Genetic algorithm, steel structure, fabrication of steel frames, minimum weight design, minimum cost design 遺伝アルゴリズム，鋼構造，鉄骨製作，最小重量設計，最小コスト設計

\section{1. 序}

建築鉄骨骨組の最適設計研究の多くは，骨組の部材断面性能を決 定する問題を扱い，その際，その単純さから断面性能又は断面寸法 の連続变数近似を利用する等, 連続変数最適化問題とする研究が行 われてきた例えば1) 6). しかし，実際の構造設計の問題は，規格断面 リストから適切な断面を選定するいわゆる離散断面最適化問題とな り, 最近は, 離散断面最適化問題を取り扱う研究も多い。また, 連 続変数最適解を出発点とした離散断面最適化手法の研究も行われて いる例えば7) 10)．離散断面最適化問題に対して，大域的最適解が得ら れることを理論的に保証することができる解法として例えば列挙法 例えば 11), 12) や分枝限定法例えば13) がある。しかし，問題の規模が大き くなると膨大な計算が必要なため, 大規模問題には適用できない. 一方，大域的最適解が得られることを理論的に保証できないが，計 算負荷が少ない手法として種々の発見的手法が提案されている. 発 見的手法には焼きなまし法例えば 14$)$ 等の単点探索法, 遺伝アルゴリズ 厶例えば15) 23) (以降では, GA と呼ぶ. ) 等の多点探索法が挙げられる.

筆者らは，これらの中から，GA に着目し研究を行っている、GA は, 感度解析が不要なため, 微分不可能な関数であっても数式化さ えできれば，どのような問題にも対応できるという長所を有してい ることから，様々な問題に適用されてきた。しかし，従来の GA は， 交叉による探索が，初期個体群の遺伝子に依存するため，一般に，
交叉の探索範囲は, 大きな設計空間の中の一部分となる.そのため, 交叉で探索できない領域を突然変異によりカバーするしくみとなっ ている. しかし, 突然変異は, 個体の遺伝子をランダムに変更する ものであり，探索の効率は悪い，そのため，例えば，骨組の規模が 大きく設計変数が多い問題や, 複雑な問題に GA を適用寸る場合には, 探索効率の改善が必要である.GAの改善については, 傾斜法例えば 24), 局所探索法例えば 25) 27), 応力による断面変更例えば 28) 29) などを GA の 中に組み込んだハイブリッド GA が提案され, その有効性が示されて いる.しかし, 例えば, 傾斜法によるハイブリッド GA では, 一般に, 探索の初期の段階で, 局所的な探索が進み寸ぎ, 局所的最適解に収 束しがちであることが指摘されている ${ }^{24)}$.

本論文では，交叉や突然変位に加えて，ランダムに選んだ設計変 数の座標軸方向への直線探索を組み込んだ GA を提案する.この提案 手法（以降では，一次元直線探索と呼ぶ.）を，鉄骨骨組の部材断面 最適化問題に適用し, 一次元直線探索の組み込みによる厳密解への 収束性及び到達率の改善効果の検証を行う。なお，厳密解とは，検 証のために列挙法により求めた解 ${ }^{12)}$ である.

本論文では 2 種類の部材断面最適化問題を扱う。一つは最小重量 設計問題で，規格断面使用により，鋼材重量が不連続に変化する. もう一つは最小コスト設計問題で, 規格断面使用により鋼材コスト が不連続に変化することに加えて, 接合部のダイアフラム数や溶接

\footnotetext{
* (株)竹中工務店広島支店設計部

** 広島大学 助教・博士 (工学)
}

*** 広島大学 教授.工博
Takenaka Corporation, Building Design Department Hiroshima Branch Office Assistant Prof., Hiroshima Univ., Dr. Eng.

Prof., Hiroshima Univ., Dr. Eng. 
接合面積が変化することにより鉄骨製作コストが不連続に変化し， 最小重量設計問題より複雑な設計問題である。例示する鉄骨骨組は 3 層と 5 層の 2 種類である. 骨組の規模と設計問題の複雑さ両面か ら, 提案手法の収束性及び厳密解到達率の改善効果の検証を行う。

\section{2. 最小重量設計問題と最小コスト設計問題の定式化}

本論文では，建築基準法に準拠した構造設計による部材断面最適 化問題として, 図 1 のような鉄骨平面骨組の最小重量設計問題と最 小コスト設計問題を取り扱う.

\section{1 最小重量設計問題}

本論文で扱う鉄骨骨組の最小重量設計問題は以下のように記述 できる.

$$
\left.\begin{array}{l}
\text { Find } D_{i d c}(i d c=1, \ldots, N D C), H_{i d b}(i d b=1, \ldots, N D B) \\
\text { which minimize } F=\rho \sum_{i=1}^{N M} A_{i} L_{i} \\
\text { subjected to } \\
g_{L i}=\frac{N_{L i}}{A_{i} f_{N L i}}+\frac{M_{L i}}{Z_{i} f_{M L i}} \leq 1 \quad(i=1,2, \ldots, N M) \\
g_{S i}=\frac{N_{S i}}{A_{i} f_{N S i}}+\frac{M_{S i}}{Z_{i} f_{M S i}} \leq 1 \quad(i=1,2 \ldots, N M) \\
g_{D k}=\frac{\delta_{k} / H_{k}}{1 / 200} \leq 1 \quad(k=1,2 \ldots, N F) \\
g_{C B R k}=\sum_{i} M_{P C K i} / \sum_{i} 1.5 M_{P B k i} \geq 1(k=1, \ldots ., N F) \\
g_{P}=\lambda_{P} \geq 1
\end{array}\right\}
$$

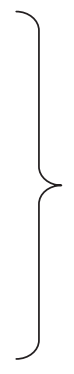

$D_{i d c}$ は，鋼管柱の規格断面番号を示寸．また， $H_{i d b}$ は， H 形鋼梁 の規格断面番号を示す．これらの部材断面は，表 1 ，表 2 で示され ている規格断面リストより選定される， NDC, NDB, NM は，それ ぞれ柱設計変数の総数, 梁設計変数の総数, 部材総数である.

最小重量設計問題における, 目的関数 F は, 骨組部材の総重量で ある. $\rho, A_{i}, L i$ は, それぞれ鋼材比重, 部材断面積, 部材長である. $g_{L i}$ は, 鈆直荷重時に関する制約関数. $g_{S i}$ は, 鉛直および水平の同時 荷重時に関する制約関数. $g_{D k}$ は, 層間変形角の制約関数を示す. $g_{C B R k}$ は, 柱梁耐力比の制約関数. $g_{P}$ は, 骨組の崩壊荷重に対する制約関 数である. $N_{i}, M i, f_{N i}, f_{M i}, Z i$ は各部材の軸力, 曲げモーメント, 軸力と曲げの許容応力度, 断面係数である. $\delta_{k}, H_{k}, N F$ は, 各層の 層間変形, 階高および階数である. $M_{P C K i}, M_{P B K i}$ は, 柱梁の部材耐 力を示す． $\lambda_{p}$ は，設計用水平荷重に対する崩壊機構形成時の荷重倍 率を示寸.

\section{2 最小コスト設計問題}

本論文で扱う鉄骨骨組の最小コスト設計問題は次のように記述 できる.

Find $D_{i d c}(i d c=1, \ldots, N D C), H_{i d b}(i d b=1, \ldots, N D B)$

which minimize

$$
F=C F+K S \cdot\left(\rho \sum_{i=1}^{N M} A_{i} L_{i}+\rho \sum_{i=1}^{N J} V_{D i}\right)
$$

subjected to Eq. (3a-e)

最小コスト設計問題における，目的関数 $F$ は，鉄骨製作コストと 鋼材コストの合計コスト（以降では，単に合計コストと呼ぶ.）であ る. $C F$ は, 文献 30) で示した鉄骨製作コスト, $K S$ は, 鋼材単価, $V_{D}$ は, $i$ 番目の接合部のダイアフラム体積, $N J$ は, 接合部総数である.
簡単のため, ダイアフラム板厚は, 接合する梁フランジ板厚に $3 \mathrm{~mm}$ を加えた厚さとする．また，ダイアフラム出寸法の部分は，体積に 算定していない.

\section{3 無制約最小化問題への変換}

前述の式(1)～式 (5)の問題は，制約条件付最小化問題であるが， この問題に GA を適用するため, 次のような無制約の最小化問題に変 換する. 2.1 の最小重量設計問題及び, 2.2 の最小コスト設計問題を 無制約の最小化問題に変換したものを式(6), 式(7)に示す.

$F^{*}=(1+\Delta G) \cdot F$

$\Delta G=\sum_{g_{L i}>1}\left(g_{L i}-1\right)+\sum_{g_{S i}>1}\left(g_{S i}-1\right)+\sum_{g_{D_{k}}>1}\left(g_{D k}-1\right)+\sum_{g_{C B R k}<1}\left(1-g_{C B R k}\right)+\sum_{g_{P}<1}\left(1-g_{P}\right)$ ここで, $\sum_{g>1}$ は, $\mathrm{g}>1$ を満足するもの, $\sum_{g<1}$ は, $g<1$ を満足する ものの総和で, 制約条件の逸脱度を表す.

\section{3. 計算手法}

\section{1 改善前 GA}

本論文では, 一次元直線探索を組み込まない従来型の GA を改善前 $\mathrm{GA}$ とよび，一次元直線探索を組み込んだ GA を改善後 GA とよぶ. 改善前 GA は，文献 17）18）に示寸ようなランク戦略に基づく手順 で実行することができる，個体 $i$ の遺伝子型は，各部材グループ（以 降では, 設計変数という。）に割り当てられる規格断面番号を決定す るための 0 以上 1 以下の実数值（遺伝子）群 $R_{i l}, R_{i 2} . ., R_{i N D}$ をそのまま 一列に並べた形（実数コード）とする. ここで, $N D$ は, 設計変数

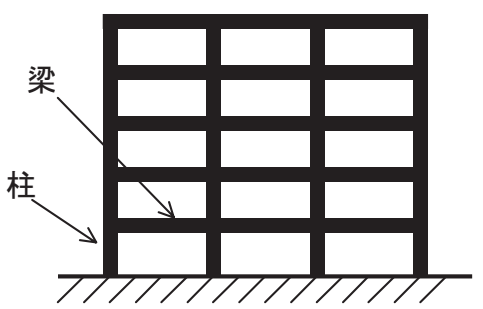

図 1 鉄骨平面骨組

表 1 角形鋼管柱 BCR295 の断面リスト

\begin{tabular}{|c|c|c|}
\hline 部材成系列 & $\begin{array}{c}\text { 規格断面番号 } \\
\text { ID }\end{array}$ & 部材サイズ \\
\hline \multirow{4}{*}{$\square 350$ 系列 } & 1 & $\square-350 \times 12$ \\
\cline { 2 - 3 } & 2 & $\square-350 \times 16$ \\
\cline { 2 - 3 } & 3 & $\square-350 \times 19$ \\
\hline \multirow{3}{*}{$\square 400$ 系列 } & 4 & $\square-350 \times 22$ \\
\cline { 2 - 3 } & 5 & $\square-400 \times 16$ \\
\cline { 2 - 3 } & 6 & $\square-400 \times 19$ \\
\hline \multirow{3}{*}{$\square 450$ 系列 } & 8 & $\square-400 \times 22$ \\
\cline { 2 - 3 } & 9 & $\square-450 \times 16$ \\
\hline \multirow{2}{*}{$\square 500$ 系列 } & 10 & $\square-450 \times 19$ \\
\cline { 2 - 3 } & 11 & $\square-500 \times 19$ \\
\hline
\end{tabular}

表 2 JIS 規格 H 形鋼梁 SN400 の断面リスト

\begin{tabular}{|c|c|c|c|}
\hline \multicolumn{2}{|c|}{ 部材成系列 } & $\begin{array}{c}\text { 規格断面番号 } \\
\text { ID }\end{array}$ & 部材サイズ \\
\hline $\mathrm{H} 400$ 系列 & 細幅 & 1 & $\mathrm{H}-400 \times 200 \times 8 \times 13$ \\
\hline \multirow{2}{*}{$\mathrm{H} 500$ 系列 } & 細幅 & 2 & $\mathrm{H}-500 \times 200 \times 10 \times 16$ \\
\cline { 2 - 4 } & 中幅 & 3 & $\mathrm{H}-500 \times 300 \times 11 \times 18$ \\
\hline \multirow{2}{*}{$\mathrm{H} 600$ 系列 } & 細幅 & 4 & $\mathrm{H}-600 \times 200 \times 11 \times 17$ \\
\cline { 2 - 4 } & 中幅 & 5 & $\mathrm{H}-600 \times 300 \times 12 \times 20$ \\
\hline $\mathrm{H} 700$ 系列 & 細幅 & 6 & $\mathrm{H}-700 \times 300 \times 13 \times 24$ \\
\hline
\end{tabular}


総数である.実数コードの表現型 (規 格断面番号） 一の変換方法は, 文献 19)に示されている. 遺伝子長は, 設 計変数の総数に等しくなる. 交叉に は，最も単純で基本的な交叉である 一点交叉を採用している.改善前 GA では, 一般に交叉位置は, 2 進数コ ードの任意位置とするが,ここでは, 遺伝子の区切りの箇所で等確率に発 生するようにしている. 前方の遺伝 子情報と後方の遺伝子情報をどちら の親から得るかも等確率でランダム に決定する. 突然変異については, すべての遺伝子をある確率（突然変 異確率）で選択していき, 選択され た遺伝子を新たな乱数で置き換えて いる。

\section{2 一次元直線探索}

\section{2.1 一次元直線探索の計算手順}

図 2 に示寸門型平面骨組に一次元 直線探索を適用した場合の概念図を 図 3 に示寸. 図 2 に示寸門型平面骨 組の場合, $R_{i l}$ は個体 $i$ の柱断面, $R_{i 2}$ は個体 $i$ の梁断面に対応寸る遺伝子 を示寸. 図 3 中のの印は同世代の個 体を意味している，ここで全個体の 全設計変数から, 指定確率 $P 1$ で一 次元直線探索を実行する設計変数を 選定（以降では, 特定設計変数と呼 ぶ. ) する. 特定設計変数として個体 $i$ の $R_{i 2}$ が選定された場合, $R_{i 1}$ の規格 断面は固定したままで, $R_{i 2}$ を全規格 断面の中から順次変更することで派 生する個体全ての $F^{*}$ を計算する. 図 3 中の縦方向に並んだ○印は, $R_{i 2}$ が 採用可能な全規格断面を順次変更し た場合の個体 $i$ からの派生個体を意 味している。次に, 個体 $i$ と全派生 個体の $F^{*} の$ 中で, 最小の $F^{*}$ を与え る規格断面に個体 $i$ の $R_{i 2}$ を変更す る。これにより, 最適設計解への収 束性及び到達率が改善されると考え

\section{られる。}

図 4 に, 改善後 $\mathrm{GA}$ の計算手順を示 す.改善後 GA の大きな計算の流れは, 改善前 $\mathrm{GA}$ の計算手順の中の「NI個 の個体の $F^{*}$ 計算」の後に, 一次元 直線探索の計算手順を行い, 再び, 改善前 GA の計算手順に戻る.
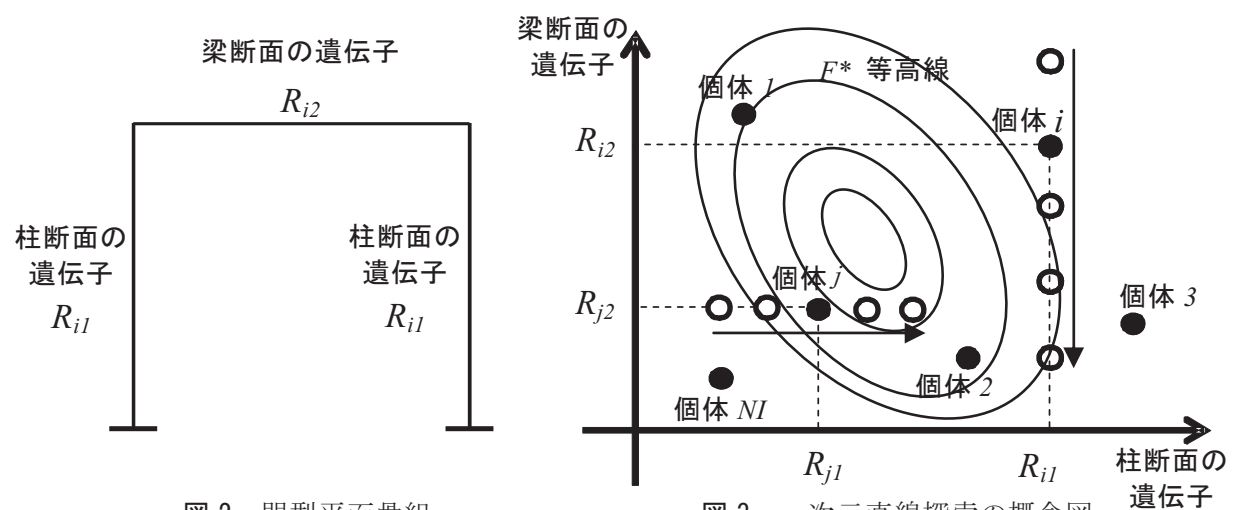

図 2 門型平面骨組

遺伝子

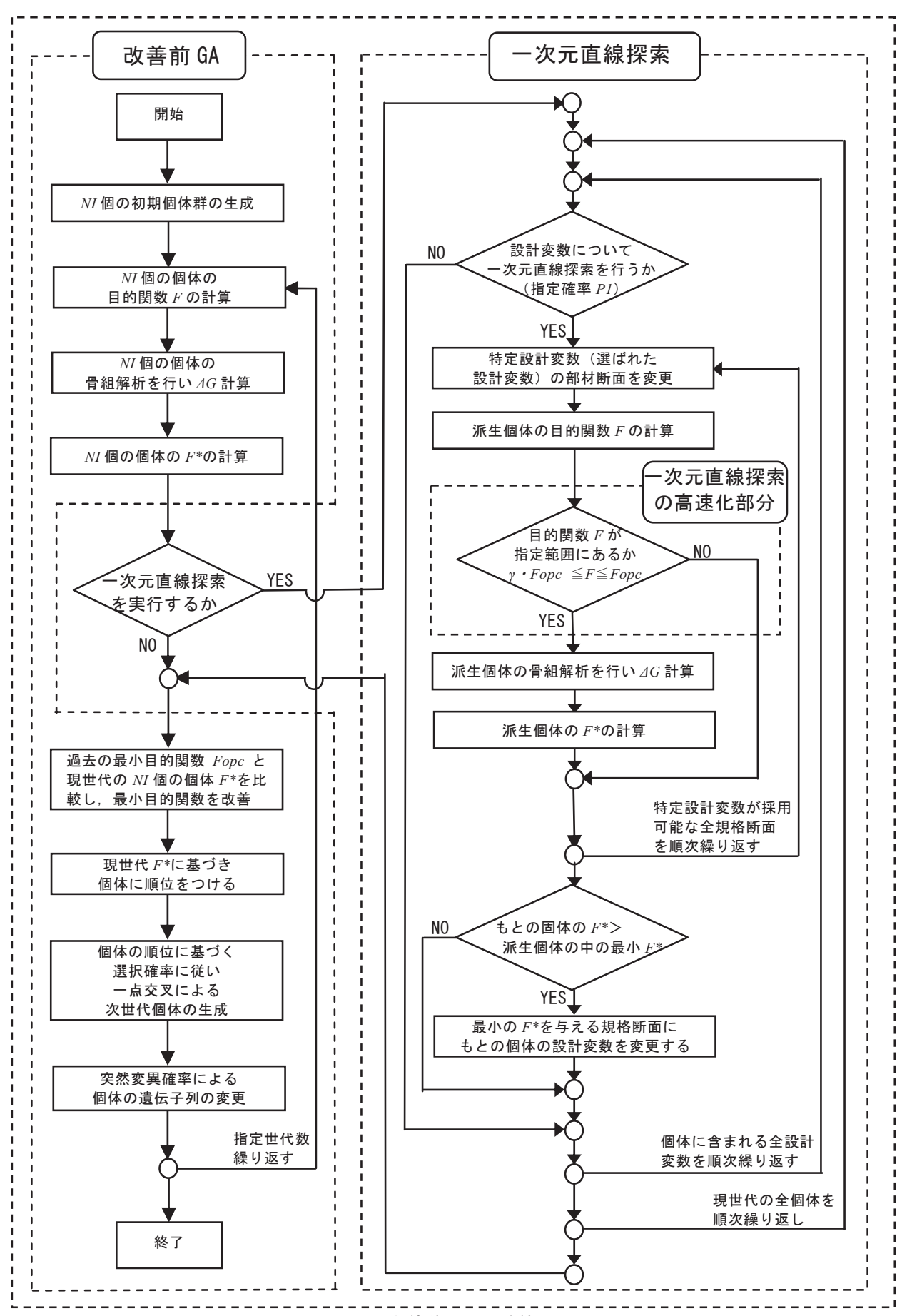

図 4 改善後 GA の計算手順 


\section{2.2 目的関数值制限に基づく一次元直線探索の高速化}

一次元直線探索で全派生個体の計算を行うと，一連の計算回数が 改善前 GA よりも増加し計算時間が長くなる場合がある. ところで, 式 (7) の制約条件の逸脱度 $\Delta G$ の計算には, 骨組解析が必要であり計 算負荷が大きいが，式 (2)，式(5)の目的関数值 $F$ の計算は，骨組解 析より負荷はずっと少ない，そこで，一次元直線探索を行う派生個 体の $F$ が, 式(8) を満足する場合に, その派生固体の骨組解析を実 施し，反対に，その派生個体の F が Fop c を上回る場合には，最適 設計解となる可能性が無く，また，その派生個体の F が $\gamma \cdot F o p c$ を 下回るならば，その派生固体が制約条件を満足する可能性が低いと 考え，そのような場合にはその派生個体を捨て，骨組解析をスキッ プして次の派生個体の探索に移ることとする。これにより最適設計 解となる可能性が低い派生固体の骨組解析回数を大きく低減し，計 算時間の短縮が期待される.

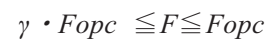

ここで, Fopc：その時点までで制約条件を満足する個体の中 での最小の目的関数值, $\gamma$ : 派生個体の目的関数值の下限值を 決める係数 $(0 \leqq \gamma<1)$.

目的関数值制限に基づく一次元直線探索の高速化は，図 4 の「派 生個体の目的関数 $F$ の計算」の後に行っている.

\section{4. 数值検証に用いる解析モデル}

\section{13 層 3 スパン平面骨組}

図 5 に 3 層 3 スパン平面骨組(以降では 3 層骨組と呼ぶ. ) を示す。 設計変数は, 柱, 各層外梁, 各層内梁の計 7 変数とする

鉛直荷重は，固定荷重と積載荷重の和として $7.84\left(\mathrm{kN} / \mathrm{m}^{2}\right)$ を, 水 平荷重については, 弾性制約に対して標準層せん断力係数 $\mathrm{C}_{0}=0.2$ の $\mathrm{Ai}$ 分布層せん断力を用いるが, 塑性制約に対しては, Ds $=0.4$ とした 地震力を用いている. 使用寸る部材断面は 2 章の表 1 , 表 2 に示し

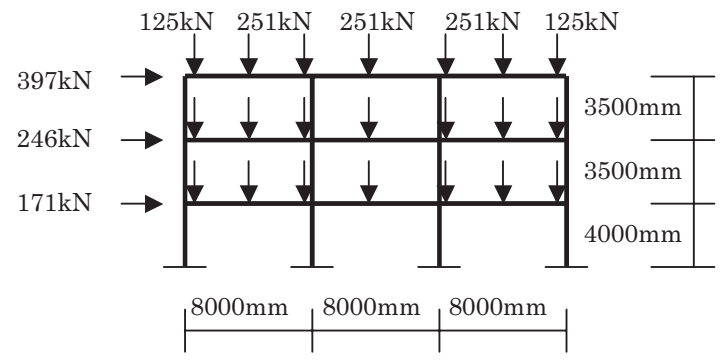

図 53 層 3 スパン平面骨組

$188 \mathrm{kN} \quad 141 \mathrm{kN} \quad 188 \mathrm{kN}$

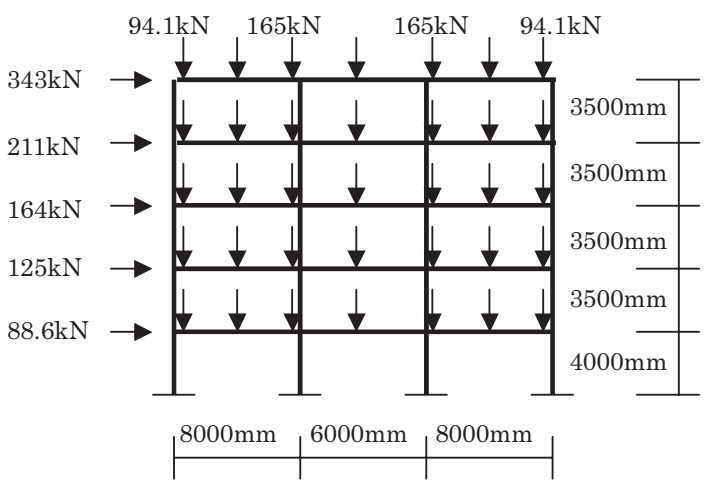

図 65 層 3 スパン平面骨組
た規格断面である，柱部材は角形鋼管（BCR295），梁部材は細幅・中 幅 H 形鋼（SN400）である。ヤング係数 E は $2.06 \times 10^{5}\left(\mathrm{~N} / \mathrm{mm}^{2}\right)$ として いる. コスト算出に用いる鋼材の材料単価は 4079 円/kN（4 万円/卜 ン) とした。表 3 に 3 層骨組の列挙法による最小重量設計問題と最 小コスト設計問題の厳密解 ${ }^{12)}$ を示す。この厳密解は GA の改善効果 を評価する基準として用いる。 3 層骨組の場合, 最小重量設計解と 最小コスト設計解の断面寸法，骨組重量，コストは同じである.

\section{25 層 3 スパン平面骨組}

図 6 に 5 層 3 スパン平面骨組（以降では 5 層骨組と呼ぶ.）を示 す. 設計変数は, 下層部 ( 1,2 層), 上層部 $(3,4,5$ 層) の柱，各層 外梁, 各層内梁の計 12 変数である.

鉛直荷重は, 固定荷重と積載荷重の和として $6.72\left(\mathrm{kN} / \mathrm{m}^{2}\right)$ とし, 水 平荷重及び，規格断面リスト，基準強度，ヤング係数，鋼材の材料 単価は，3層骨組に同じである。

表 4 に 5 層骨組の列挙法による最小重量設計問題と最小コスト設 計問題の㛜密解 ${ }^{12)}$ を示寸。この峳密解は GA の改善効果を評価する 基準として用いる.

表 33 層骨組の最小重量設計解と最小コスト設計解の断面寸法

\begin{tabular}{|l|l|r|r|r|r|}
\hline & & $\mathrm{A}\left(\mathrm{cm}^{2}\right)$ & $\mathrm{I}\left(\mathrm{cm}^{4}\right)$ & $\mathrm{Z}\left(\mathrm{cm}^{3}\right)$ & $\mathrm{Z}_{\mathrm{p}}\left(\mathrm{cm}^{3}\right)$ \\
\hline $1,2,3$ 層柱 & $\square-400 \times 16$ & 237.0 & 57,100 & 2,850 & 3,370 \\
\hline 3層外梁 & $\mathrm{H}-500 \times 200 \times 10 \times 16$ & 112.2 & 46,800 & 1,870 & 2,130 \\
\hline 2層外梁 & $\mathrm{H}-600 \times 200 \times 11 \times 17$ & 131.7 & 75,600 & 2,520 & 2,900 \\
\hline 1層外梁 & $\mathrm{H}-500 \times 300 \times 11 \times 18$ & 159.2 & 68,900 & 2,820 & 3,130 \\
\hline 3層内梁 & $\mathrm{H}-500 \times 200 \times 10 \times 16$ & 112.2 & 46,800 & 1,870 & 2,130 \\
\hline 2層内梁 & $\mathrm{H}-600 \times 200 \times 11 \times 17$ & 131.7 & 75,600 & 2,520 & 2,900 \\
\hline 1層内梁 & $\mathrm{H}-500 \times 300 \times 11 \times 18$ & 159.2 & 68,900 & 2,820 & 3,130 \\
\hline 柱梁重量 & \multicolumn{5}{|c|}{$154.75 \mathrm{kN}$} \\
\hline コスト & \multicolumn{5}{|c|}{$7,842,543$} \\
\hline
\end{tabular}

表 4 (A) 5 層骨組の最小重量設計解の断面寸法

\begin{tabular}{|l|l|r|r|r|r|}
\hline & & $\mathrm{A}\left(\mathrm{cm}^{2}\right)$ & $\mathrm{I}\left(\mathrm{cm}^{4}\right)$ & $\mathrm{Z}\left(\mathrm{cm}^{3}\right)$ & $\mathrm{Z}_{\mathrm{p}}\left(\mathrm{cm}^{3}\right)$ \\
\hline 3,4,5層柱 & $\square-400 \times 16$ & 237.0 & 57,100 & 2,850 & 3,370 \\
\hline 1,2層柱 & $\square-450 \times 16$ & 269.0 & 82,900 & 3,690 & 4,330 \\
\hline 5層外梁 & $\mathrm{H}-500 \times 200 \times 10 \times 16$ & 112.2 & 46,800 & 1,870 & 2,130 \\
\hline 4層外梁 & $\mathrm{H}-500 \times 200 \times 10 \times 16$ & 112.2 & 46,800 & 1,870 & 2,130 \\
\hline 3層外梁 & $\mathrm{H}-600 \times 200 \times 11 \times 17$ & 131.7 & 75,600 & 2,520 & 2,900 \\
\hline 層外梁 & $\mathrm{H}-500 \times 200 \times 10 \times 16$ & 112.2 & 46,800 & 1,870 & 2,130 \\
\hline 1層外梁 & $\mathrm{H}-500 \times 200 \times 10 \times 16$ & 112.2 & 46,800 & 1,870 & 2,130 \\
\hline \hline 5層内梁 & $\mathrm{H}-400 \times 200 \times 8 \times 13$ & 83.37 & 23,500 & 1,170 & 1,310 \\
\hline 4層内梁 & $\mathrm{H}-400 \times 200 \times 8 \times 13$ & 83.37 & 23,500 & 1,170 & 1,310 \\
\hline 層内梁 & $\mathrm{H}-600 \times 300 \times 12 \times 20$ & 187.2 & 114,000 & 3,890 & 4,350 \\
\hline 2層内梁 & $\mathrm{H}-700 \times 300 \times 13 \times 24$ & 231.5 & 197,000 & 5,640 & 6,340 \\
\hline 1曾内梁 & $\mathrm{H}-700 \times 300 \times 13 \times 24$ & 231.5 & 197,000 & 5,640 & 6,340 \\
\hline 柱梁重量 & \multicolumn{5}{|c|}{$247.13 \mathrm{kN}$} \\
\hline コス卜 & \multicolumn{5}{|c|}{} \\
\hline
\end{tabular}

表 4 (B) 5 層骨組の最小コスト設計解の断面寸法

\begin{tabular}{|l|l|r|r|r|r|}
\hline & & $\mathrm{A}\left(\mathrm{cm}^{2}\right)$ & $\mathrm{I}\left(\mathrm{cm}^{4}\right)$ & $\mathrm{Z}\left(\mathrm{cm}^{3}\right)$ & $\mathrm{Z}_{\mathrm{p}}\left(\mathrm{cm}^{3}\right)$ \\
\hline 3,4,5層柱 & $\square-400 \times 16$ & 237.0 & 57,100 & 2,850 & 3,370 \\
\hline 1,2層柱 & $\square-400 \times 19$ & 277.2 & 65,400 & 3,270 & 3,900 \\
\hline 5層外梁 & $\mathrm{H}-500 \times 200 \times 10 \times 16$ & 112.2 & 46,800 & 1,870 & 2,130 \\
\hline 4層外梁 & $\mathrm{H}-500 \times 200 \times 10 \times 16$ & 112.2 & 46,800 & 1,870 & 2,130 \\
\hline 層外梁 & $\mathrm{H}-600 \times 200 \times 11 \times 17$ & 131.7 & 75,600 & 2,520 & 2,900 \\
\hline 2層外梁 & $\mathrm{H}-600 \times 200 \times 11 \times 17$ & 131.7 & 75,600 & 2,520 & 2,900 \\
\hline 1層外梁 & $\mathrm{H}-600 \times 300 \times 12 \times 20$ & 187.2 & 114,000 & 3,890 & 4,350 \\
\hline 5層内梁 & $\mathrm{H}-500 \times 200 \times 10 \times 16$ & 112.2 & 46,800 & 1,870 & 2,130 \\
\hline 4層内梁 & $\mathrm{H}-500 \times 200 \times 10 \times 16$ & 112.2 & 46,800 & 1,870 & 2,130 \\
\hline 層内梁 & $\mathrm{H}-600 \times 200 \times 11 \times 17$ & 131.7 & 75,600 & 2,520 & 2,900 \\
\hline 2層内梁 & $\mathrm{H}-600 \times 300 \times 12 \times 20$ & 187.2 & 114,000 & 3,890 & 4,350 \\
\hline 1層内梁 & $\mathrm{H}-600 \times 200 \times 11 \times 17$ & 131.7 & 75,600 & 2,520 & 2,900 \\
\hline 柱梁重量 & \multicolumn{5}{|c|}{$254.97 \mathrm{kN}$} \\
\hline コス卜 & \multicolumn{5}{|c|}{} \\
\hline
\end{tabular}




\section{5. 解析結果}

\section{1 改善前 GA の解析結果}

4 節に示した 3 層および 5 層骨組の最小重量設計問題および最小 コスト設計問題に対する改善前 GA の解析結果を示寸.GA の個体数 NI は 50 個体とし，世代数は 300 世代とした。

図 7 に, 目的関数值の平均值 (乱数を変えた 5 回の実行の平均值) の履歴を示す，縦軸は，目的関数平均值の悠密解に対する比率．横 軸は，計算時間の代用値として骨組解析回数で示寸。これより，層 数が増加すると, 厳密解への収束性が悪くなる傾向が確認できる. また，最小重量問題より複雑な最小コス卜設計問題の方が厳密解へ の収束性が悪くなる傾向が確認できる。また，いずれの解析ケース においても骨組解析回数約 5000 回前後で各解析ケース固有の值に 収束する傾向を示す。

図 8 に, 各設計問題において, 乱数を変えた 5 回の実行の中で, 目的関数值が最も良い収束履歴を示した実行結果（以降では，最良 結果と呼ぶ.) を示す. 縦軸は, 目的関数值の厳密解に対する比率. 横軸は, 骨組解析回数である. 3 層骨組の最小重量設計問題と最小 コスト設計問題は, 目的関数平均值では収束性に明らかな差が見ら れたが，最良結果は，ほぼ同程度の収束傾向を示している．5層骨 組では, 目的関数平均值と同様に, 最小コスト設計問題の方が最小 重量問題より厳密解への収束性が悪くなる傾向が確認でき，その収 束值の差は目的関数平均值の差よりも大きい.

図 9 に, 乱数を変えた 5 回の実行において, 目的関数值が厳密解 に到達した時点の骨組解析回数とその厳密解到達率（ここでは，厳 密解の $0.1 \%$ 誤差の範囲内にあるものを正解と判定して, 到達率を 算定した。以降でも同様としている.）の履歴を示す，縦軸は，峳密 解到達率，横軸は，骨組解析回数である。3 層骨組では，最小重量 設計問題が骨組解析回数約 1800 回で，最小コスト設計問題では約 3100 回で，80\%の到達率を示しているが，5 層骨組では，いずれの設 計問題においても骨組解析回数 15000 回までの到達率は $0 \%$ ある. これより, 骨組の規模が大きく設計変数が多い問題や, 最小重量設 計問題よりも問題が複雑な最小コス卜設計問題では, 局所的最適解 に陷りやすいため GA の厳密解への収束性や厳密解到達率が低下寸 ることが確認された。

\section{2 改善後 GA の解析結果}

\section{2.1 最小重量設計問題}

4 節に示した 3 層および 5 層骨組の最小重量設計問題に対する一 次元直線探索を組み込んだ $\mathrm{GA}$ (以降では, 単に改善後 $\mathrm{GA}$ と呼ぶ. ) の解析結果を示す. 解析に用いた個体数 NI は 50 個体. 探索確率 P1 は，P1 值を変えてケーススタディーを行った結果から，50\%を選択 した. 目的関数值制限に基づく高速化考慮における $\gamma$ は 0.8 とした。

図 10, 図 14 に, 3 層および 5 層骨組で得られた目的関数值である 骨組重量の平均值の履歴を示寸。縦軸は, 骨組重量平均值の厳密解 に対する比率．横軸は，骨組解析回数である．３層骨組，5 層骨組の いずれに対しても, 改善後 GA は改善前 GA に比べて厳密解への収束 性が良く，改善効果が認められる。

図 11, 図 15 に，3 層および 5 層骨組における最良結果を示す。縦 軸は, 骨組重量の厳密解に対する比率。横軸は, 骨組解析回数であ る. 3 層骨組では, 改善前 GA も改善後 GA も，厳密解に到達してい る．改善後 GA は改善前 GA より少ない骨組解析回数で厳密解に収束

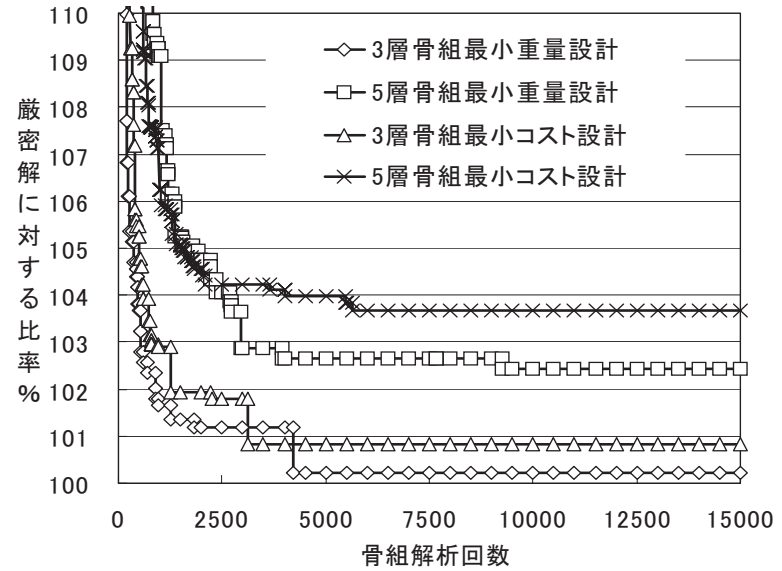

図 7 改善前 $\mathrm{GA}$ による目的関数平均值

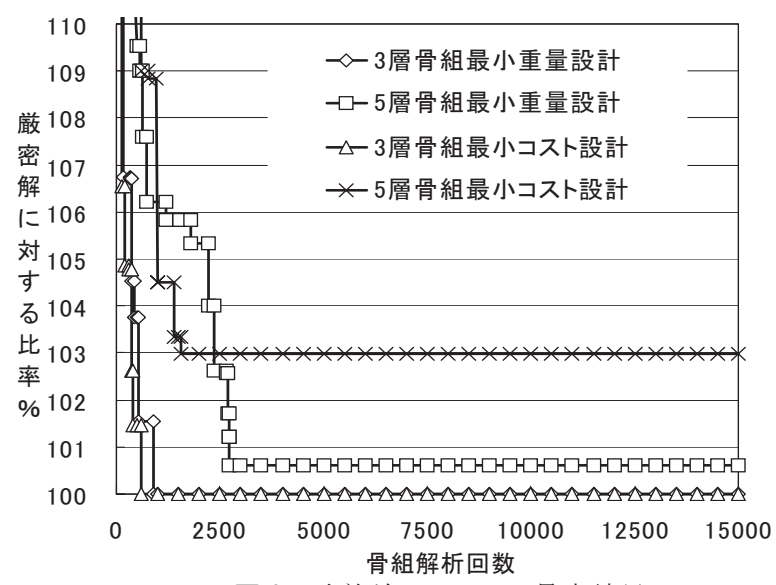

図 8 改善前 GAによる最良結果

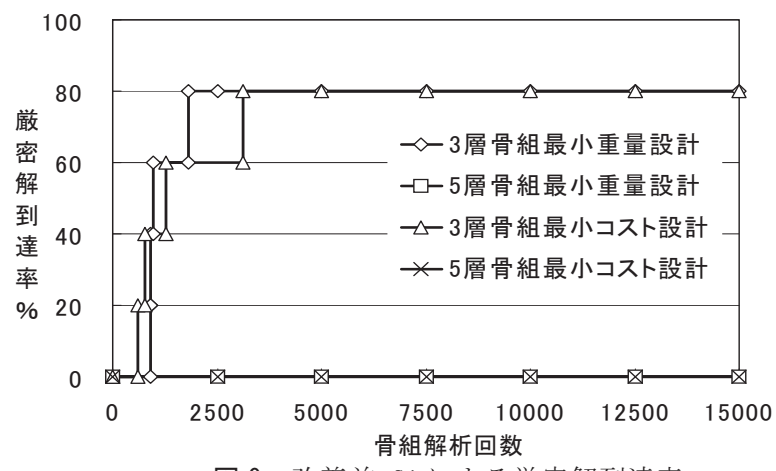

図 9 改善前 GA による厳密解到達率

しており，改善効果が認められる５層骨組では，改善前 $\mathrm{GA}$ は厳密 解に到達していないが, 改善後 GA は厳密解に到達しており, 改善効 果が認められる. 図 12 , 図 16 に, 3 層および 5 層骨組における乱数 を変えた 5 回の実行の中で, 目的関数值が最も悪い収束履歴を示し た実行結果（以降では，最悪結果と呼ぶ.）を示す。これは，実務設 計などで極めて少ない回数の実行で済ませたい場合を念頭においた ものである. 3 層骨組，5 層骨組のいずれにおいても改善前 GA は厳 密解に到達していないが，改善後 GA は，厳密解に到達しており, 改 善効果が認められる。改善効果は 5 層骨組において顕著である。こ れらの図より，3層骨組，5層骨組のいずれにおいても，改善後 GA の最悪結果の収束值は, 改善前 $\mathrm{GA}$ の最良結果の収束值以下であるこ とが確認できる. 


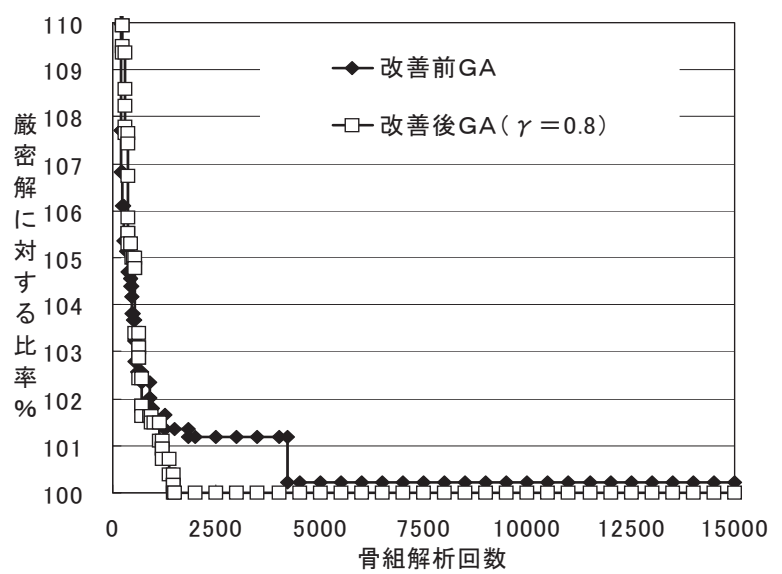

図 103 層骨組の最小重量設計における骨組重量平均值

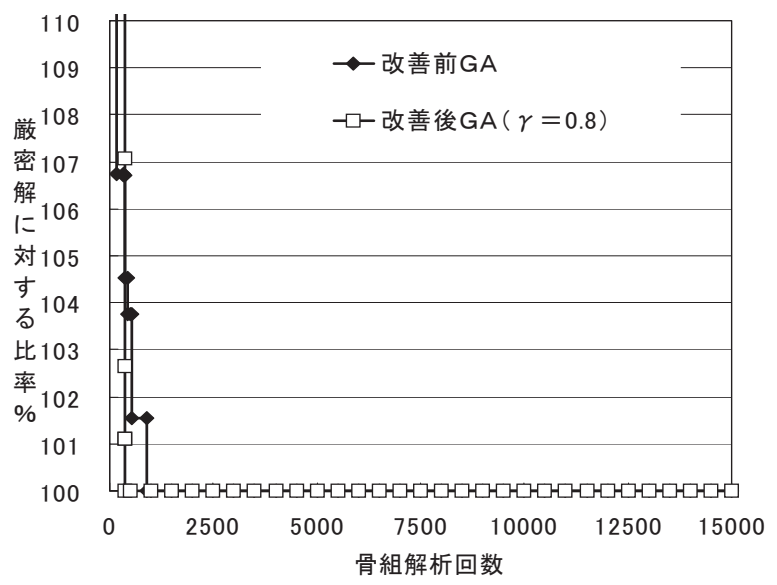

図 113 層骨組の最小重量設計における最良結果

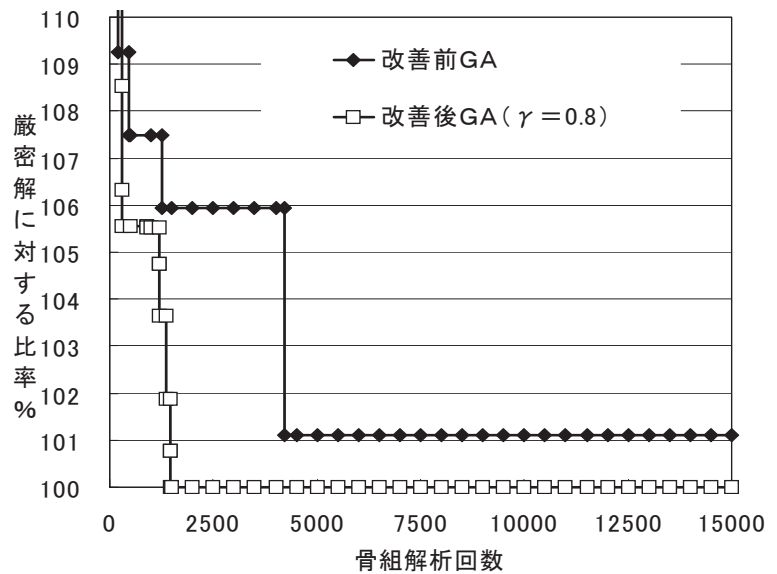

図 12 3 層骨組の最小重量設計における最悪結果

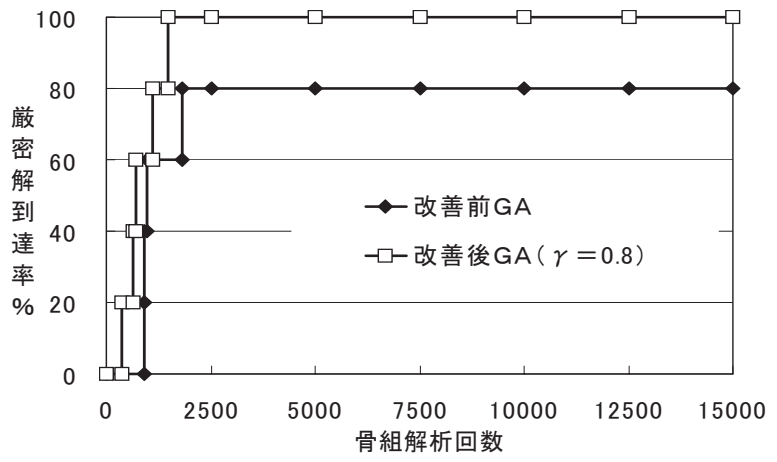

図 133 層骨組の最小重量設計における厳密解到達率

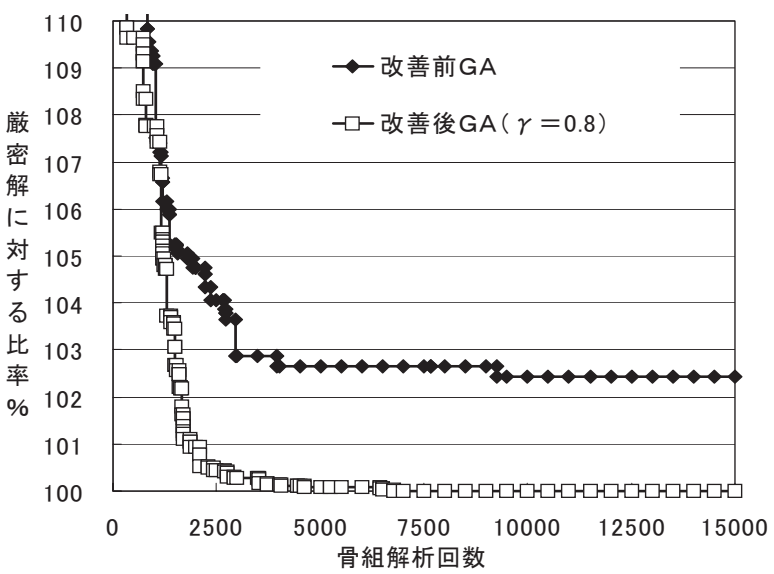

図 145 層骨組の最小重量設計における骨組重量平均值

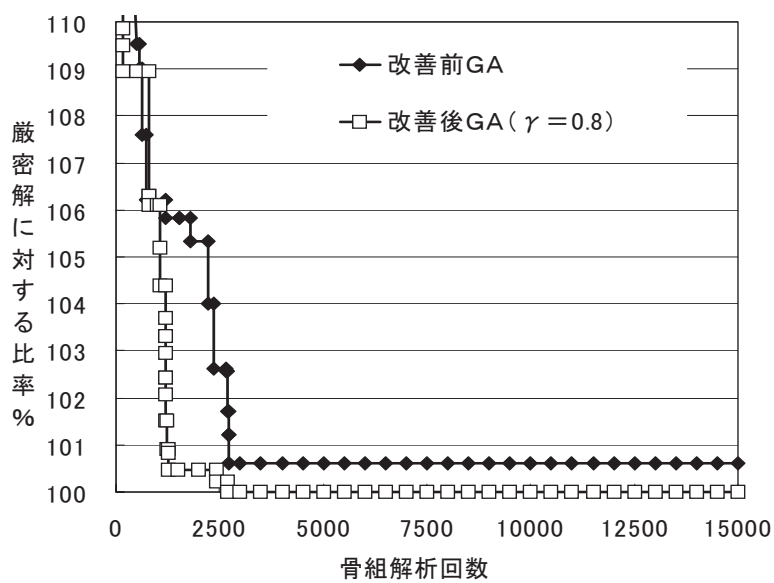

図 155 層骨組の最小重量設計における最良結果

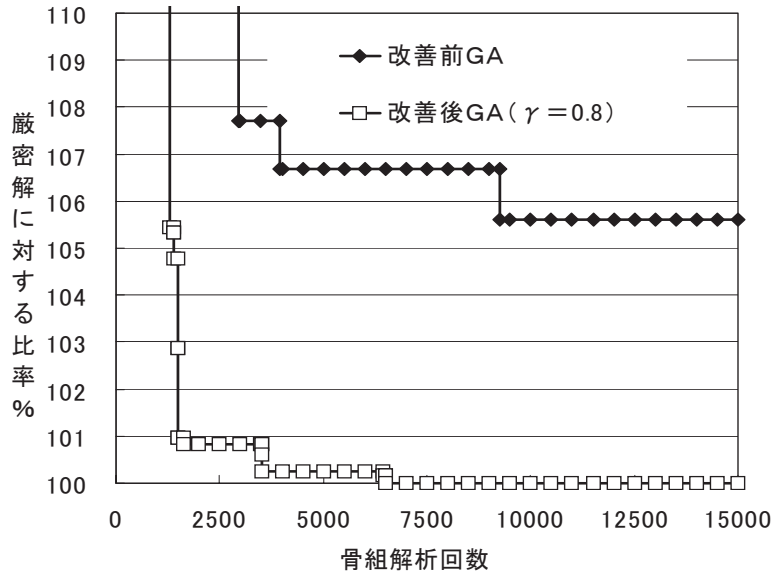

図 16 5 層骨組の最小重量設計における最悪結果

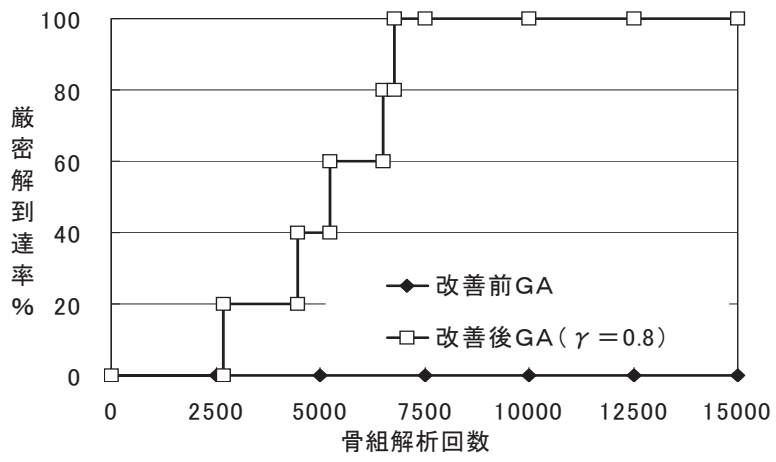

図 175 層骨組の最小重量設計における厳密解到達率 


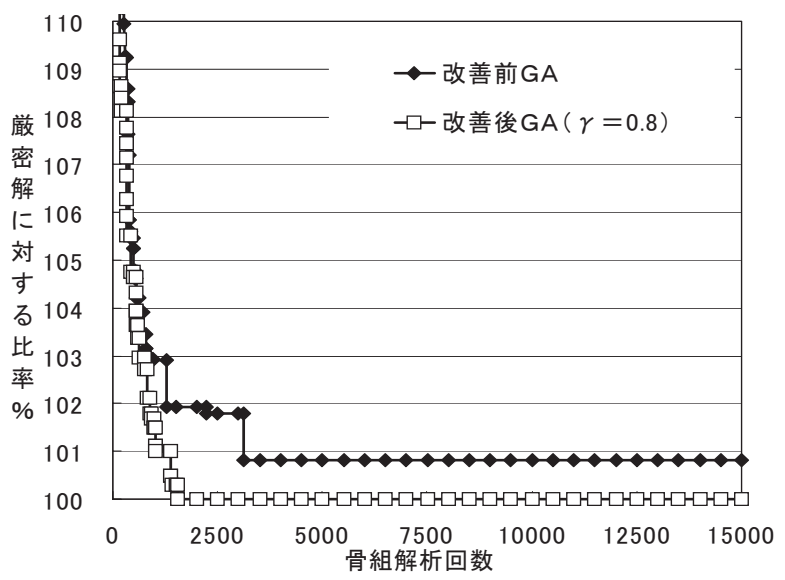

図 183 層骨組の最小コスト設計における合計コスト平均值

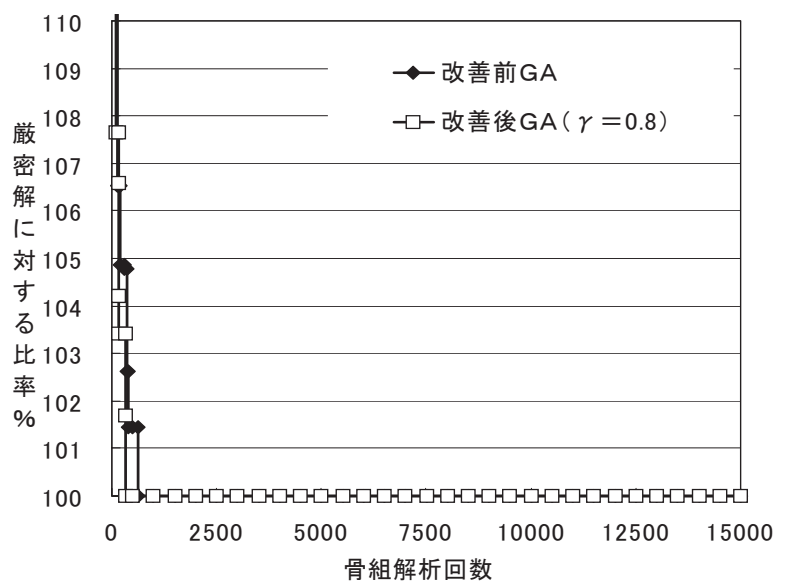

図 193 層骨組の最小コスト設計における最良結果

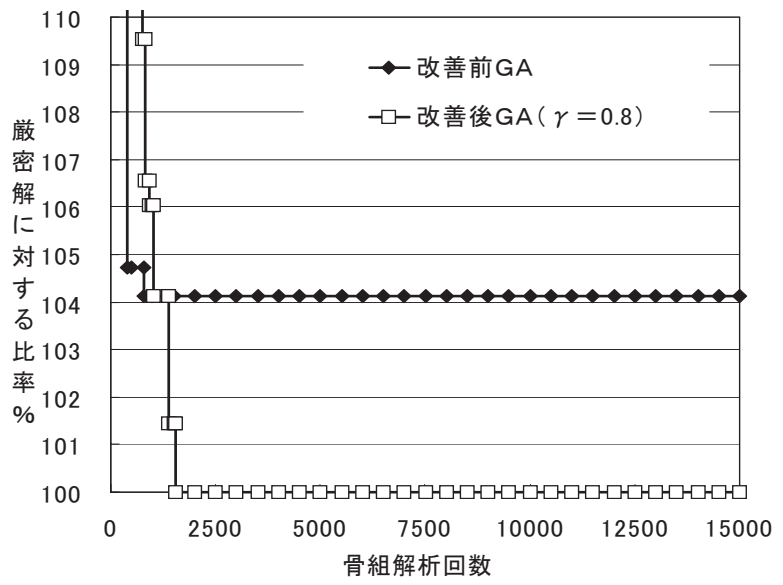

図 203 層骨組の最小コスト設計における最悪結果

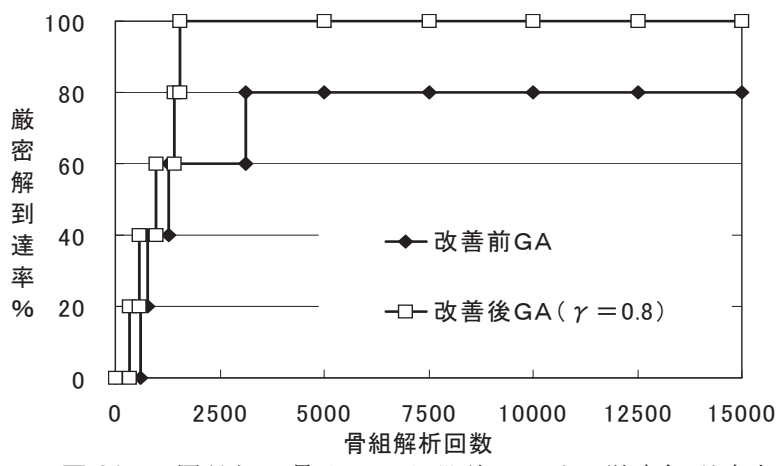

図 213 層骨組の最小コスト設計における厳密解到達率

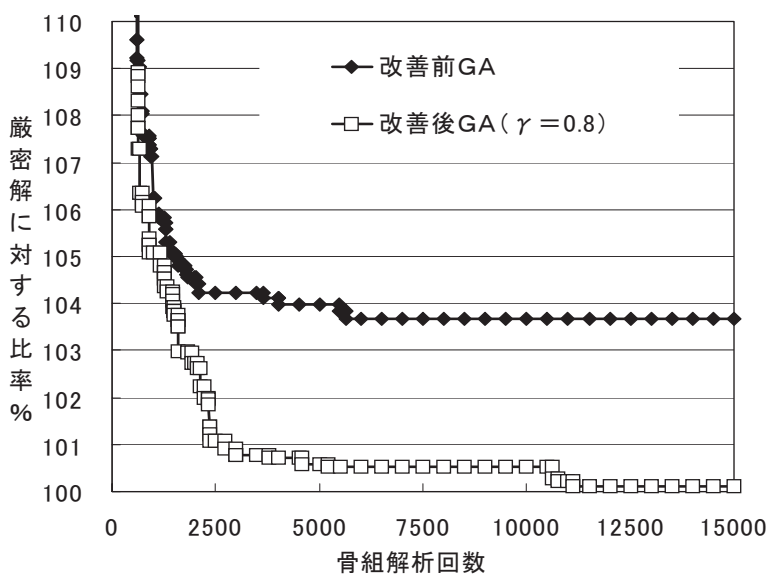

図225 層骨組の最小コスト設計における合計コスト平均値

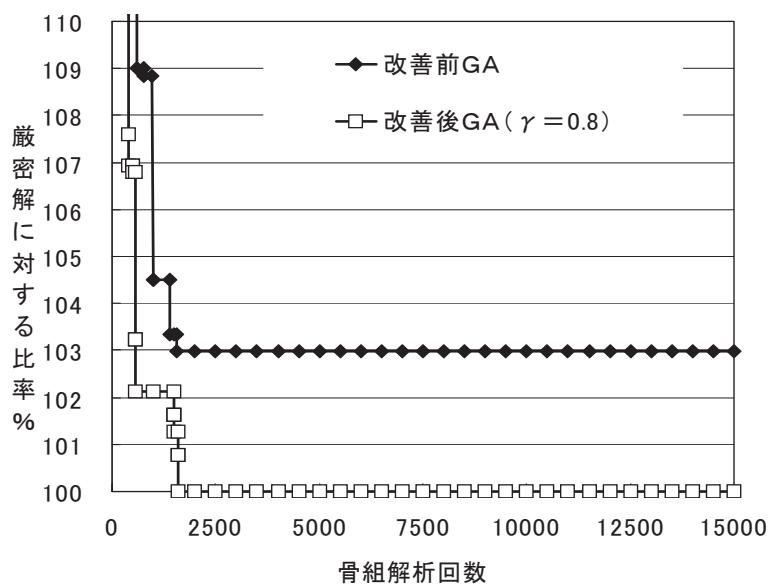

図 235 層骨組の最小コスト設計における最良結果

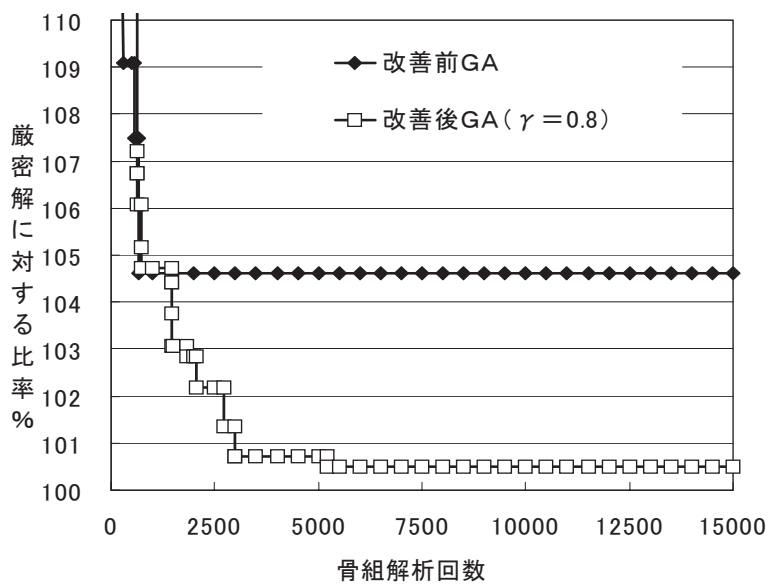

図 245 層骨組の最小コスト設計における最悪結果

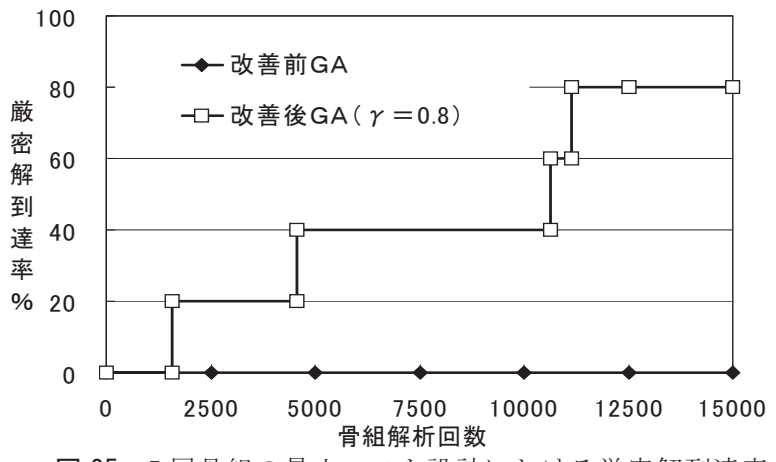

図 255 層骨組の最小コスト設計における厳密解到達率 
図 13, 図 17 に, 3 層および 5 層骨組において, 乱数を変えた 5 回 の実行において, 骨組重量が悠密解に到達した時点の骨組解析回数 とその厳密解到達率の履歴を示寸. 縦軸は, 厳密解到達率. 横軸は, 骨組解析回数である. 3 層骨組では, 改善後 GA は骨組解析回数約 1500 回までに, 100\%の厳密解到達率を示しており, 改善前 GAに比べて改 善効果が認められる. 5 層骨組では, 改善前 GA が骨組解析回数 15000 回までに $0 \%$ 厳密解到達率であるが, 改善後 $\mathrm{GA}$ では骨組解析回数 約 6800 回までに, 100\%の厳密解到達率を示しており, 改善効果が認 められる。

\section{2.2 最小コスト設計問題}

4 節に示した 3 層および 5 層骨組の最小コスト設計問題に対する 改善後 GA の解析結果を示寸. 解析に用いた個体数, 探索確率 P1, 目的関数值制限に基づく高速化考慮における $\gamma$ は，5.2.1 に示した 最小重量設計問題と同じ条件としている.

図 16, 図 19 に，3 層および 5 層骨組で得られた目的関数值である 合計コストの平均值の履歴を示す. 3 層骨組, 5 層骨組のいずれに対 しても, 改善後 GA は改善前 GA に比べて峳密解への収束性が良く, 改善効果が認められる.

図 18, 図 22 に，3 層および 5 層骨組における最良結果を示す． 3 層骨組では, 改善前 GA も改善後 GA も, 厳密解に到達している. 改 善後 GA は改善前 GA より若干ではあるが少ない骨組解析回数で厳密 解に収束しており，改善効果が認められる。 5 層骨組では，改善前 $\mathrm{GA}$ は厳密解に到達していないが，改善後 $\mathrm{GA}$ では局所的最適解に収 束することなく厳密解に収束しており，改善効果が認められる。図 20，図 24 に，3層および 5 層骨組における最悪結果を示す． 3 層骨 組では, 改善前 GA は厳密解に到達していないが，改善後 GA は厳密 解に到達しており, 改善効果が認められる. 5 層骨組では, 改善前 $\mathrm{GA}$ も改善後 GA も，厳密解に到達していないが，改善前 GA が厳密解 の約 104.5\%に収束しているのに対し，改善後 GA は厳密解の $100.5 \%$ に到達しており，改善効果が認められる。これらの図より， 3 層骨 組, 5 層骨組のいずれにおいても, 改善後 GA の最悪結果の収束值は, 改善前 $\mathrm{GA}$ の最良結果の収束值以下であることが確認できる.

図 21, 図 25 に, 3 層および 5 層骨組において, 乱数を変えた 5 回 の実行において, 合計コストが厳密解に到達した時点の骨組解析回 数とその厳密解到達率の履歴を示す. 3 層骨組では, 改善後 GA は骨 組解析回数約 1600 回までに, 100\%の厳密解到達率を示しており, 改 善前 GA に比べて改善効果が認められる. 5 層骨組では, 改善前 GA が骨組解析回数 15000 回まで $0 \% の$ 厳密解到達率であるが, 改善後 GA では骨組解析回数約 1600 回で初回の厳密解到達の後, 約 11200 回で 80\%の厳密解到達率を示しており，改善効果が認められる.

\section{2.3 目的関数值制限に基づく高速化の効果確認}

3.2 .2 に示した目的関数值制限に基づく高速化の効果を確認する ため, 改善後 GA の高速化考慮と高速化なしの比較を行う. 以下の解 析に用いた個体数，探索確率 P1 は，5.2.1，5.2.2 と同じ条件とし ている. 図 26〜図 29 に，乱数を変えた 5 回の実行において，目的 関数が厳密解に到達した時点の骨組解析回数とその厳密解到達率の 履歴を 3 層骨組，5層骨組それぞれの最小重量設計問題と最小コス 卜設計問題について示す。これらの図には，改善前 GA，改善後 GA の高速化なし，高速化考慮の $\gamma$ が $0.5,0.8,0.9,0.975$ の 6 種類の結 果について示している. 図 26 , 図 28 の 3 層骨組では設計問題に関

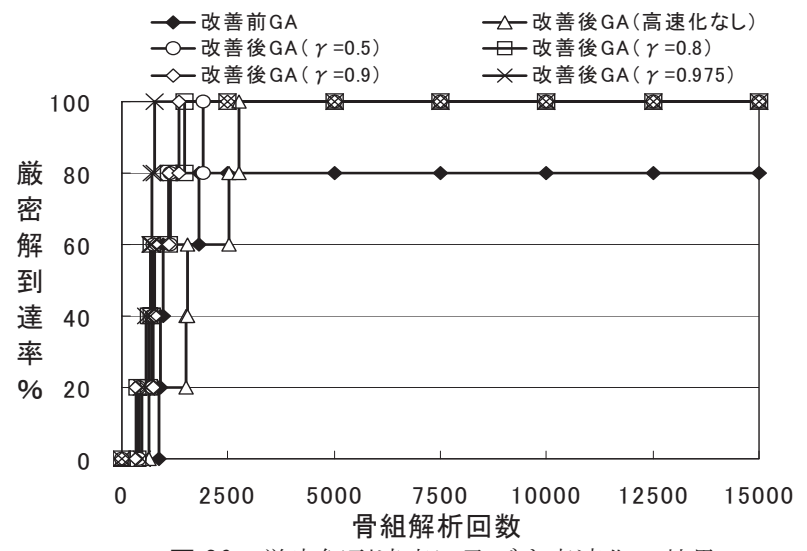

図 26 厳密解到達率に及ぼす高速化の効果

（3 層骨組・最小重量設計）

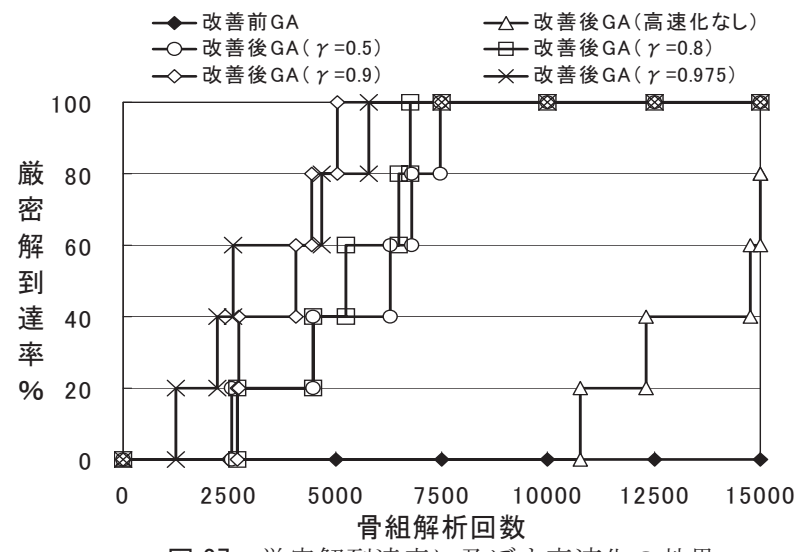

図 27 㛜密解到達率に及ぼす高速化の効果 (5 層骨組・最小重量設計)

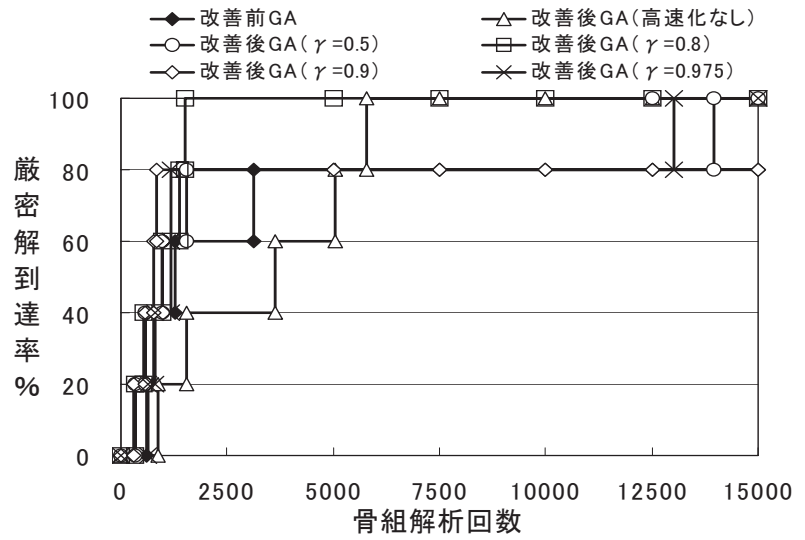

図 28 厳密解到達率に及ぼす高速化の効果 (3 層骨組・最小コスト設計)

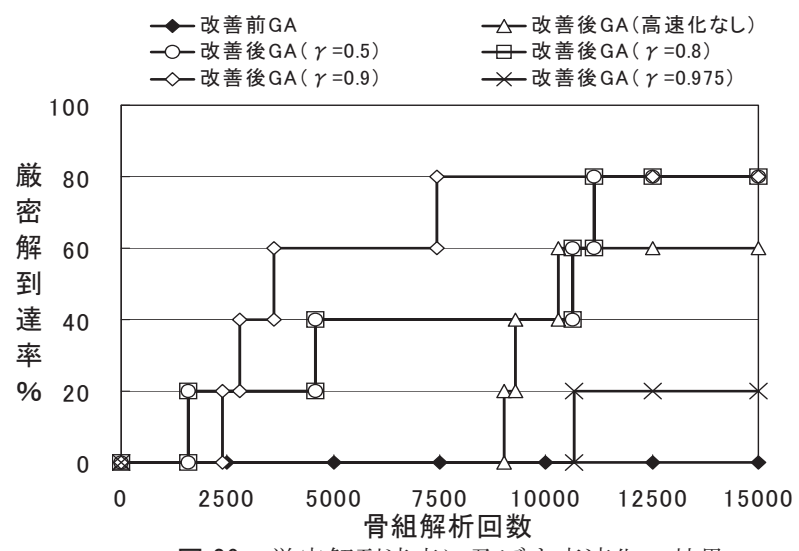

図 29 厳密解到達率に及ぼす高速化の効果 (5 層骨組・最小コスト設計) 
わらず，高速化なしでも骨組解析回数 15000 回までの厳密解到達率 は 100\%となり改善前 GA の 80\%よりも改善されているが，厳密解に 到達する骨組解析回数が増加する傾向を示す。これは一次元直線探 索により最適解になる可能性の低い派生個体の骨組解析を多数行っ ているためである. 図 27, 図 29 の 5 層骨組では設計問題に関わら ず，高速化なしでも改善前 GAより厳密解到達率は改善されている. これは, 規模が大きくなると, 一次元直線探索による派生個体から 最適解が生まれることを示している.

図 26, 図 27 の最小重量設計問題では, 高速化なしに比較して高 速化により厳密解に到達するための骨組解析回数を低減することが できている，その低減効果は 3 層骨組より 5 層骨組の方が大きい. $\gamma$ の違いによる解析結果への影響は顕著ではなく, 5 層骨組の場合に

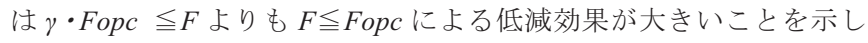
ている. 図 28 の 3 層骨組最小コス卜設計問題では, 厳密解到達率 $80 \%$ までは $\gamma$ の違いによる解析結果への影響は顕著ではないが, 㛜密 解到達率 $100 \%$ への到達は $\gamma=0.8$ の場合が最も骨組解析回数が少ない 結果を示している. 図 29 の 5 層骨組最小コスト設計問題では, $\gamma=0.975$ とした場合に高速化なしよりも厳密解到達率が低下してい るが， $\gamma$ が 0.9 以下の場合に厳密解到達率は改善されている。 $\gamma$ が 0.8 と 0.5 の場合には同一の解析結果であり, $\gamma$ が 0.8 より小さい值 では改善効果に大きな差がないことを示している.

図 30 に, 5 層骨組の最小コスト設計問題に対する, 目的関数の平 均值の履歴を示寸. 改善後 $\mathrm{GA}$ の高速化考慮 $(\gamma=0.8)$ では, 5.2.2 で述べたように改善前 GA に対して目的関数の収束性が改善されて いるが，高速化なしではその目的関数の収束性は緩やかであり，骨 組解析回数を多くなると高速化考慮に近い㛜密解への収束性を示す が, 骨組解析回数が約 5000 回以下の少ない段階では, 改善前 GA よ りも収束性が悪い.

図 31 に, 5 層骨組の最小コスト設計問題に対する, 最良結果を示 す. 高速化なしでは, 厳密解に到達する骨組解析回数は約 9000 回で あるが，高速化考慮では，約 1600 回で厳密解に到達しており, 高速 化考慮の改善効果が認められる。

以上より，一次元直線探索に高速化を考慮することにより，豲密 解到達率の改善と厳密解に到達寸るための骨組解析回数を低減する ことができる，言い換えると，計算時間を短縮しながら計算性能の 改善ができる.その改善効果は 3 層骨組より 5 層骨組の方が大きい.

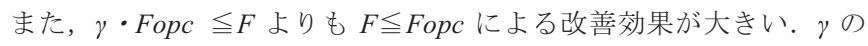
值は 0.975 等の極端に小さな值を設定しなければ改善効果を期待で き, 本論文で示した規模の最適設計問題では, $\gamma=0.8 \sim 0.9$ 程度が 推奨される.

\section{6. 結論}

本論文では, 骨組の規模が大きく設計変数が多い問題や, 最小重 量設計問題よりも問題が複雑で厳密解到達率が低下寸る最小コスト 設計問題に対する GA の計算性能を改善するため,一次元直線探索を 組み込んだ $\mathrm{GA}$ を提案した。

提案した一次元直線探索の内容は, 全個体の全設計变数から, 指 定確率で一次元直線探索を実行する特定設計変数をランダムに選定 し，その特定設計変数を全規格断面の中から順次変更していき，目 的関数值 $F^{*}$ が最小となる規格断面に変更するというものである.

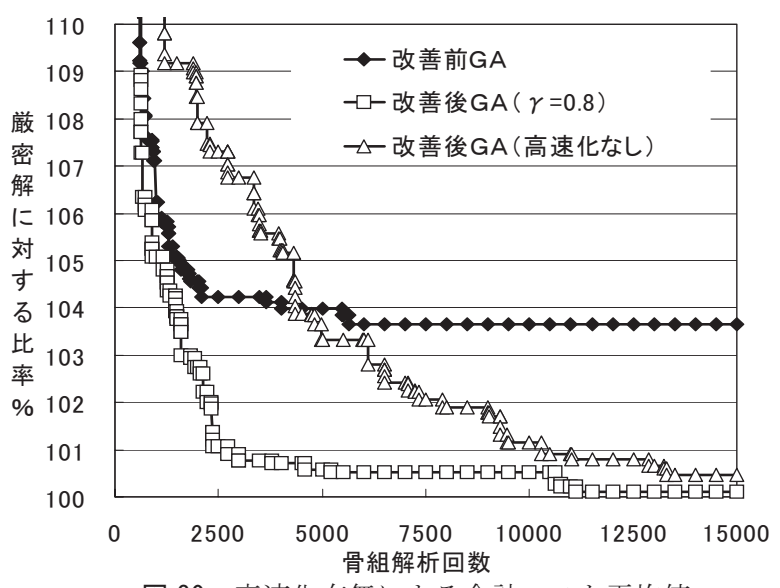

図 30 高速化有無による合計コスト平均值 （5 層骨組・最小コスト設計）

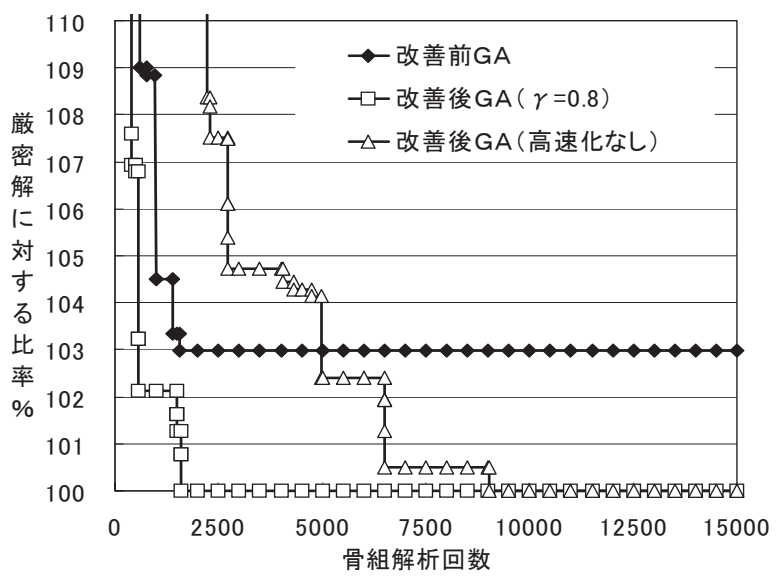

図 31 高速化有無による最良結果

（5 層骨組・最小コスト設計）

この提案手法を 3 層骨組と 5 層骨組の最小重量設計問題と最小コス 卜設計問題に適用し，改善後 GA が，3 層骨組及び 5 層骨組の両方に おいて，また最小重量設計問題及び，最小コスト設計問題のいずれ においても, 㛜密解への収束性, 厳密解到達確率が改善前 GA よりも 高く, 改善効果が大きいことを検証した。 また，今回用いた乱数の 範囲では, いずれの乱数を用いても改善後 GA の収束值が改善前 $\mathrm{GA}$ の収束值以下となることを確認した.

加えて, 一次元直線探索における目的関数值制限に基づく高速化 を提案した。高速化考慮の有無を 3 層骨組と 5 層骨組の最小重量設 計問題と最小コスト設計問題に適用し，高速化を考慮することによ り, 計算時間を短縮しながら計算性能の改善ができることを示した.

今後は, 改善後 $\mathrm{GA}$ を実設計に適用するため, さらに骨組の規模が 大きく設計変数が多い設計例における解の収束性と計算時間の確認 等により, GA の中で用いる各種パラメータの整備が検討課題である と考えている。

\section{謝辞}

本研究は, 文部科学省科学研究費補助金 (若手研究 (B) 平成 21 年 度〜22 年度. 研究代表者 : 澤田樹一郎, 題目 : 鉄骨建築構造の製作 コストを考慮した最小コスト設計手法）の助成を受けて行われまし た.この場を借りて感謝の意を表します. 


\section{参考文献}

1) K. Uetani, M. Tsuji, I. Takewaki : Application of an optimum design method to practical building frames with viscous dampers and hysteretic dampers, Engineering Structures 25(2003), pp. 579 592

2) D. M. Brown and A.H. -S. Ang : Structural Optimization by Nonlinear Programming, J. of Struct. Eng. Div. ASCE, Vol. 92, ST6, pp. 319 340, 1966

3）田中尚, 中村雄治：建築構造物の自動設計と最適設計, 培風館, 1973

4）中村恒善, 小坂郁夫：弾塑性骨組の指定設計用変形指標に対する 2 段階 地震応答制約設計法, 日本建築学会構造系論文集, No. 439, pp. 89 101, 1992.9

5）澤田樹一郎, 中村雄治, 松尾彰 : 反復線形計画法を用いた平面ラーメン の最適弾性・塑性設計法, 日本建築学会構造系論文集, No. 485, pp. 117 $126,1996.7$

6）内村均，長縄裕行，和田章：部材塑性率に注目した水平荷重を受ける鉄 骨造平面骨組の部材断面変更法, 日本建築学会構造系論文集, No. 537, pp. $69 \sim 76,2000.11$

7) A. A. Groenwold, N. Stander and 3. A. Snyman: A pseudo-discrete rounding method for structural optimization, Structural 0ptimization 11, pp. 218〜227, 1996

8）竹脇出，杉山哲彦，辻聖晃，上谷宏二：縮約モデル-骨組逆置換法に基づ く骨組設計法, 日本建築学会構造系論文集, No. 512, pp. 119～125, 1998. 10

9）澤田樹一郎, 周岩, 松尾彰, 中村雄治：部材せい設計変数を考慮した鋼 構造建築骨組の最小重量設計に関寸る研究，日本建築学会構造系論文 集, No. 544, pp. 133〜139, 2001.6

10）吉富信太，山川誠，上谷宏二：二段階緩和法に基づく鋼構造骨組の最適 離散断面選択法，日本建築学会構造系論文集, No. 586, pp. 95～100, 2004. 12

11）澤田樹一郎，松尾彰：弾性・塑性制約下における鋼構造建築骨組の離散 最適化問題に対する列挙型アルゴリズムの改善解法, 日本建築学会構造 系論文集, No. 574,pp. 93〜98, 2003. 12

12）澤田樹一郎，佐々木尊一，松尾 彰，清水 斉：改善列挙法による工場製 作コストを考慮した鉄骨骨組の最小コスト設計, 第 31 回情報・システム・ 利用・技術シンポジウム, 2008. 12

13) M. Stolpe : Global optimization of minimum weight truss topology problems with stress, displacement, and local buckling constraints using branch-and-bound, Int. J. Numer. Meth. Engng, 61, pp. 1270 1309, 2004

14) M. Ohsaki, T. Kinoshita and P. Pan, Multiobjective heuristic approaches to design of frames with standard sections, Earthquake Engng. Struct. Dyn. , Vol. 36 (11), pp. 1481 1495, 2007

15) JOHN H. HOLLAND, GENETIC ALGORITHMS AND THE OPTIMAL ALLOCATION OF TRIALS, SIAM J. COMPUT., Vol. 2, No. 2, 1973

16）田村 尚土，大森 博司：多目的最適化法による鋼構造物の構造設計支援 手法の提案：その 1 許容応力度等設計における最適設計法, 日本建築 学会構造系論文集, No. 628, pp. 891〜897, 2008.6

17）大崎純：遺伝的アルゴリズム基づく不連続コスト関数を有する構造物の 最適設計法, 日本建築学会構造系論文集, No. 464, pp. 119-127, 1994. 10

18) W. M. Jenkins : Plane frame optimum design environment based on genetic algorithm, ASCE, Vol. 118 (11), pp. 3103 3112, 1992

19）澤田樹一郎，松尾彰，Dai Qing Song，重量制限を課した遺伝アルゴリズ ムによる鋼構造建築ラーメン骨組の最小重量設計, 日本建築学会構造系 論文集, No. 600, pp. 89〜96, 2006.2

20) C. Camp, S. Pezeshk, G. Cao : Optimized Design of Two-Dimensional Structures Using a Genetic Algorithm, J. of Struct. Engng., Vol. 124, pp. 551 559, 1998

21）大森博司，鬼頭伸彰：遺伝的アルゴリズムを用いたトラス構造物の形態 創出，日本建築学会構造系論文集, No. 520, pp. 85 92, 1999.6

22)W. Gutkowski, Z. Iwanow and J.Bauer : Controlled mutation in evolutionary structural optimization, Struct. Multidisc. Optim. 21, pp. $355 \sim 360,2001$
23) G. Guerlement, R. Targowski, W. Gutkowski, J. Zawidzka, J. Zawidzki : Discrete Minimum Weight Design of Steel Structures Using EC3 Code, Struct. Multidisc. Optim., 22, pp. 322 327, 2001

24）廣安知之, 三木光範，南泰彦，谷村勇輔：傾斜法を用いたハイブリッド 遺伝アルゴリズムの大域的最適点探索, 情報処理学会第 5 回数理モデル 化と問題解決シンポジウム論文集, pp. 57〜 64, 2000

25）柳浦睦憲，茨木俊秀：遺伝アルゴリズムと局所探索法のロバスト性につ いて, 信学技報, COMP95-23, 電子情報信学会, 1995

26) TING-YU CHEN AND CHUNG-JEI CHEN : IMPROVEMENTS OF SIMPLE GENETIC ALGORITHM IN STRUCTURAL DESIGN, INTERNATIONAL JOURNAL FOR NUMERICAL METHODS IN ENGINEERING, VOL, 40, pp. 1323〜1334, 1997

27）章 宏, 石川眞澄: 局所探索付ハイブリッド実数コード遺伝的アルゴリズ 么, 信学技報, NC2004-132, 電子情報信学会, 2005

28) MARIUSZ PYRZ : Evolutionary Algorithm Integrating Stress Heuristics for Truss 0ptimization, Optimization and Engineering, 5, pp. 45 57,2004

29) I-Cheng Yeh : Hybrid Genetic Algorithms for Optimization of Truss Structures, Computer Aided Civil and Infrastructure Engineering 14 (1999), pp. 199 206

30）佐々木尊一, 清水斉, 澤田樹一郎，松尾彰，南波篤志：労務時間記録に 基づく鉄骨製作コストの簡易評価に関する研究, 鋼構造年次論文報告集, 第 15 巻, pp. $79 \sim 84,2007.11$

（2009年 5 月22日原稿受理，2009年10月23日採用決定） 